\title{
Evidence of co-metabolic bentazone transformation by methanotrophic enrichment from a groundwater-fed rapid sand filter
}

Hedegaard, Mathilde Jørgensen; Deliniere, Hélène; Prasse, Carsten; Dechesne, Arnaud; Smets, Barth F.; Albrechtsen, Hans-Jørgen

Published in:

Water Research

Link to article, DOI:

10.1016/j.watres.2017.10.073

Publication date:

2018

Document Version

Peer reviewed version

Link back to DTU Orbit

Citation (APA):

Hedegaard, M. J., Deliniere, H., Prasse, C., Dechesne, A., Smets, B. F., \& Albrechtsen, H-J. (2018). Evidence of co-metabolic bentazone transformation by methanotrophic enrichment from a groundwater-fed rapid sand filter. Water Research, 129, 105-114. https://doi.org/10.1016/j.watres.2017.10.073

\section{General rights}

Copyright and moral rights for the publications made accessible in the public portal are retained by the authors and/or other copyright owners and it is a condition of accessing publications that users recognise and abide by the legal requirements associated with these rights.

- Users may download and print one copy of any publication from the public portal for the purpose of private study or research.

- You may not further distribute the material or use it for any profit-making activity or commercial gain

- You may freely distribute the URL identifying the publication in the public portal 


\section{Evidence of co-metabolic bentazone transformation by methanotrophic enrichment from a groundwater-fed rapid sand filter}

Mathilde J. Hedegaard $^{l^{*}}$; Hélène Deliniere ${ }^{1}$; Carsten Prasse ${ }^{2,3}$; Arnaud Dechesne ${ }^{l}$; Barth F. Smets ${ }^{1}$; Hans-Jørgen Albrechtsen ${ }^{l}$

1 DTU Environment, Technical University of Denmark, DK-2800 Kgs. Lyngby, Denmark; ${ }^{2}$ Department of Civil and Environmental, Engineering University of California, Berkeley, CA 94720, United States; ${ }^{3}$ Department of Environmental Health and Engineering, Johns Hopkins University, Baltimore, MD 21218, United States

*Corresponding author: telephone (+45) 4525 1478, Email: mjhe@env.dtu.dk

Article published in Water Research 129 (2018), pp. 105-114.

https://doi.org/10.1016/j.watres.2017.10.073 
This is a Post Print of the article: Hedegaard et al. (2018), Water Research. https://doi.org/10.1016/j.watres.2017.10.073

\begin{abstract}
The herbicide bentazone is recalcitrant in aquifers and is therefore frequently detected in wells used for drinking water production. However, bentazone degradation has been observed in filter sand from a rapid sand filter at a waterworks with methane-rich groundwater. Here, the association between methane oxidation and removal of bentazone was investigated with a methanotrophic enrichment culture derived from methane-fed column reactors inoculated with that filter sand. Several independent lines of evidence obtained from microcosm experiments with the methanotrophic enrichment culture, tap water and bentazone at concentrations below $2 \mathrm{mg} / \mathrm{L}$ showed methanotrophic co-metabolic bentazone transformation: The culture removed $53 \%$ of the bentazone in 21 days in presence of $5 \mathrm{mg} / \mathrm{L}$ of methane, while only $31 \%$ was removed in absence of methane. Addition of acetylene inhibited methane oxidation and stopped bentazone removal. The presence of bentazone partly inhibited methane oxidation since the methane consumption rate was significantly lower at high $(1 \mathrm{mg} / \mathrm{L})$ than at low $(1 \mu \mathrm{g} / \mathrm{L})$ bentazone concentrations. The transformation yield of methane relative to bentazone normalized by their concentration ratio ranged from 58 to 158 , well within the range for methanotrophic co-metabolic degradation of trace contaminants calculated from the literature, with normalized transformation yields varying from 3 to 400 . High-resolution mass spectrometry revealed formation of the transformation products (TPs) 6-OH, 8-OH, isopropyl-OH and di-OH-bentazone, with higher abundances of all TPs in the presence of methane. Overall, we found a suite of evidence all showing that bentazone was co-metabolically transformed to hydroxybentazone by a methanotrophic culture enriched from a rapid sand filter at a waterworks.
\end{abstract}


This is a Post Print of the article: Hedegaard et al. (2018), Water Research.

https://doi.org/10.1016/j.watres.2017.10.073

\section{Introduction}

Pesticides are detected in many fresh water bodies due to their extensive use, environmental mobility and persistence. For example, in Denmark, pesticides such as bentazone, glyphosate, mecoprop (MCPP) and atrazine were detected in $49.5 \%$ of the groundwater monitoring wells in the period 1990-2015 (GEUS \& Energi- Forsynings og Klimaministeriet, 2016). According to the European Union (EU) 'Water Framework Directive' or 'Groundwater Directive', the concentration of pesticides in drinking water and groundwater should not exceed $0.1 \mu \mathrm{g} / \mathrm{L}$ for a single compound, or $0.5 \mu \mathrm{g} / \mathrm{L}$ for the sum of all pesticides (European Community, 2000; European Union, 2006). It is thus important to identify sustainable methods to remove pesticides at low concentrations (sub $\mu \mathrm{g} / \mathrm{L}$ ) from polluted water sources.

Trace contaminants can contribute to the growth of degrading bacteria if they are utilized as source of of carbon, energy or potentially nitrogen, phosphorus or sulfur (Alexander, 1994; Benner et al., 2013). However, organic trace contaminants typically occur at too low concentrations (sub $\mu \mathrm{g} / \mathrm{L}$ ) to support microbial growth and can consequently be difficult to degrade (Alexander, 1994; Benner et al., 2013). In contrast, during co-metabolic degradation the trace contaminants are degraded along with a primary growth substrate without being used as energy or carbon source (Dalton and Stirling, 1982) and thus the degrading populations do neither gain nutrients nor energy from the secondary substrate (Alexander, 1994). This mechanism has gained a lot of attention in bioremediation, since it permits microbial degradation of trace contaminants at low concentrations, by controlling the presence of the primary substrate which can be relatively inexpensive and nontoxic (e.g. $\mathrm{CH}_{4}, \mathrm{NH}_{4}{ }^{+}$) (Iwamoto and Nasu, 2001; Semprini et al., 1990; Semprini and McCarty, 1991; Semrau et al., 2010).

Examples include ammonium-oxidizing bacteria and manganese oxidizing bacteria degrading 17 $\alpha$-ethinylestradiol in wastewater treatment effluent (Forrez et al., 2009), and ammonium oxidizing bacteria degrading the pharmaceuticals ibuprofen, ketoprofen, carbamazepine, dexamethasone, and iopromide in water treatment systems (Dawas-Massalha et al., 2014; Xu et al., 2017). However, direct evidence for co-metabolic degradation can be difficult to establish. For example, biotransformation of some trace contaminants has been shown not to be directly associated with ammonia monooxygenase activity although it was linked to ammonia removal (Helbling et al., 2012).

Methane oxidizing bacteria (MOB) can co-metabolically degrade several different trace contaminants; trichloroethylene (TCE) and other chlorinated aliphatic hydrocarbons are especially well studied (e.g. Alvarez-Cohen et al., 1992; AlvarezCohen and McCarty, 1991; DiSpirito et al., 1991; Oldenhuis et al., 1989). The methane monooxygenase (MMO) is the key enzyme in methane oxidation and can oxidize trace contaminants co-metabolically (Dalton and Stirling, 1982; Semrau et al., 2010). MMO 
This is a Post Print of the article: Hedegaard et al. (2018), Water Research. https://doi.org/10.1016/j.watres.2017.10.073

can either be the particulate, membrane bound enzyme (pMMO), which is expressed by nearly all known MOBs or the soluble, cytoplasmic MMO (sMMO) which can only be expressed by some MOBs. sMMO is expressed at low copper to biomass ratios, whereas pMMO increases when this ratio increases (Semrau et al., 2013; Sirajuddin and Rosenzweig, 2015). Generally, oxidation by pMMO is limited to alkanes up to five carbon-atoms, while sMMO is less specific and able to oxidize alkanes up to eight carbon-atoms, esters, cyclic alkanes and aromatic compounds (Burrows et al., 1984; Semrau et al., 2010; Trotsenko and Murrell, 2008). Thus, methanotrophic bioremediation can be challenging due to difficulty in microbial consortia design and control (Jiang et al., 2010), but has been shown to work at field scale (Hazen et al., 2009; Strong et al., 2015).

The transformation yield ( $T_{y}$, in moles of trace contaminant (TC) per mole of methane) expresses the relative rates between consumption of the primary and secondary substrate. Since the organisms do not gain anything from co-metabolic degradation, there is a theoretical upper limit to $T_{y}$ governed by the availability of reducing energy. This theoretical upper limit is governed by the gap between total produced energy from oxidation of primary substrate (2.64 $\mathrm{moles}_{\mathrm{NADH}} / \mathrm{mole}_{\mathrm{CH} 4}$ in case of methane oxidation) and the energy used to oxidize the primary substrate, in this case methane (1 mole $\left._{\mathrm{NADH}} / \mathrm{mole}_{\mathrm{CH} 4}\right)$. The remaining energy defines the theoretical limit for oxidation of the secondary substrate, and for methane oxidation $T_{y, \max }$ is thus 1.64 molestc/mole ${ }_{\mathrm{CH} 4}$ (Anderson and Mccarty, 1997a). A degradation of the primary substrate is therefore essential to obtain co-metabolic removal of the trace contaminant in biopurification systems.

The herbicide bentazone (IUPAC: 3-Isopropyl-1H-2,1,3-benzothiadiazin-4(3H)-one2,2-dioxide) is legally used in EU (Commission, 2017). It is recalcitrant (Albrechtsen et al., 2001; Broholm et al., 2001) and mobile (Boivin et al., 2004) in aquifers and is therefore frequently detected in wells used for drinking water production (detected in $3.3 \%$ of the active waterworks wells in Denmark during 1992-2015) (GEUS \& EnergiForsynings og Klimaministeriet, 2016). In soils under aerobic conditions bentazone is biodegraded to 6-OH-bentazone (IUPAC: 6-Hydroxy-3-Isopropyl-1H-2,1,3benzothiadiazin-4(3H)-one-2,2-dioxide) and 8-OH-bentazone (IUPAC: 8-Hydroxy-3Isopropyl-1H-2,1,3-benzothiadiazin-4(3H)-one-2,2-dioxide) and 2-amino- $\mathrm{N}$ isopropyl-benzamide (AIBA, IUPAC: 2-amino-N-propan-2-ylbenzamide) (Figure 1). Hydroxylation of the phenyl ring is the primary biodegradation pathway (Huber and Otto, 1994), where e.g. $65-85 \%$ of the added bentazone is transformed to 8-OHbentazone (Knauber et al., 2000). Generally, bentazone is assumed to be hydroxylated by several fungal species (Huber and Otto, 1994), but both fungi and bacteria may contribute to biotransformation (Knauber et al., 2000). Formed transformation products are all very reactive and are thus rapidly incorporated in the soil organic soil matter (Huber and Otto, 1994). 
This is a Post Print of the article: Hedegaard et al. (2018), Water Research.

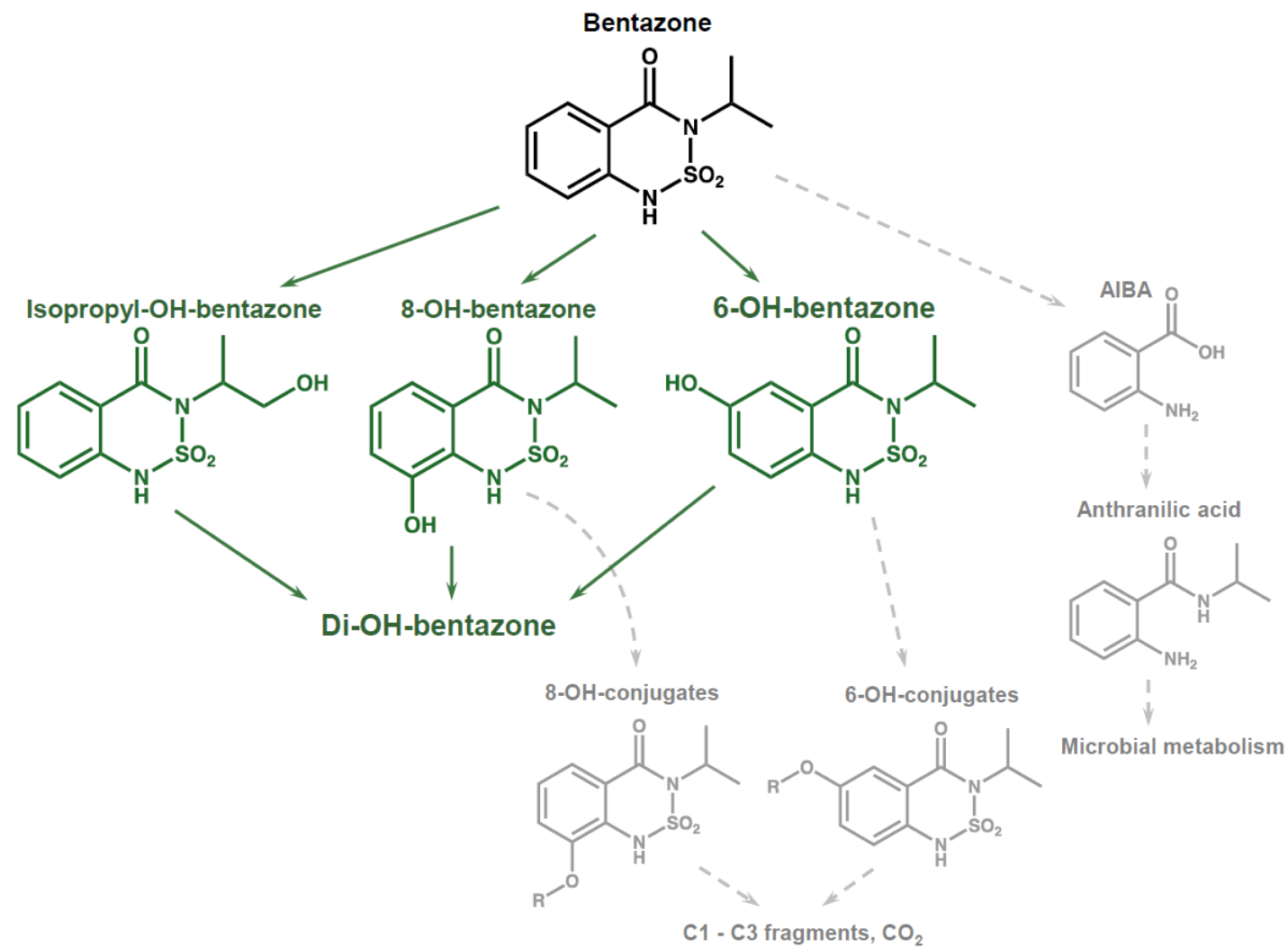

Fig. 1 Degradation pathway of bentazone. In contact with methanotrophic culture bentazone degradation led to accumulation of four transformation products (green). Isopropyl-OH-bentazone and di-OH-bentazone have, to the authors' knowledge, not previously been reported as transformation products in soil metabolism pathways (grey - incl. 6-OH- and 8-OH-bentazone) (modified from Huber and Otto, 1994).

Biological degradation of bentazone in treatment systems can be challenging: bentazone was the least degradable of four investigated pesticides (linuron, metalaxyl, isoproturon and bentazone) in an on-farm biopurification system (De Wilde et al., 2009). Therefore bentazone removal was surprising when observed in filter material from rapid sand filters from a groundwater-based waterworks (Hedegaard and Albrechtsen, 2014) receiving raw water with high methane concentrations (1.1-9.2 $\mathrm{mg} / \mathrm{L}$ before aeration) (Sjæls $\varnothing$ waterworks plant II). Ring-hydroxylation is a common initial step in the bentazone transformation (Figure 1) (Huber and Otto, 1994) and since MMO oxidizes aromatic rings co-metabolically (Semrau et al., 2010), we hypothesized that methanotrophs would be essential for the rapid transformation of bentazone in filter sand. However, co-metabolic removal assays with four pure MOB cultures reported no bentazone degradation (Benner et al., 2015). Therefore, cometabolic bentazone degradation has, to our knowledge, not yet been documented and the aim of this study was to establish direct evidence of co-metabolic degradation of bentazone by methanotrophs and determining transformation rates, yields and specificity towards methane over bentazone. Therefore, we enriched methanotrophs 
This is a Post Print of the article: Hedegaard et al. (2018), Water Research.

https://doi.org/10.1016/j.watres.2017.10.073

from a rapid sand filter showing bentazone degradation activity to investigate the interaction between methane oxidation and bentazone removal.

\section{Materials and methods}

\subsection{Growth of methanotrophic biomass in column reactors}

Methanotrophic enrichments were cultivated in four replicate continuous flow column reactors (radius $2 \mathrm{~cm}$; height $8 \mathrm{~cm}$ ), filled with expanded clay (Filtralite NC 0.8-1.6, Saint-Gobain Weber, Norway) and initially augmented (2\% v/v) with filter material from Sjæls $\varnothing$ waterworks. The column reactors were fed with drinking water with an average methane concentration of $0.6-1.4 \mathrm{mg} / \mathrm{L}$ and the average methane consumption in the reactors were $0.14-0.56 \mu \mathrm{g} \mathrm{CH} / \mathrm{min} / \mathrm{g}$ carrier material (Papadopoulou et al., n.d.).

Fresh methanotrophic biomass was collected from the column reactors for each experiment, with a growth period of more than eight weeks between collections.

\subsection{Experiment overview}

Four experiments were conducted with the methanotrophic culture in batch experiments (Table 1):

Presence of methane (PM). We investigated bentazone removal by the methanotrophic consortium and the influence of presence/absence of methane. We also examined whether bentazone transformation resulted in a production/accumulation of transformation products.

Inhibition of MMO (IMMO). Allylthiourea (ATU) (Bédard and Knowles, 1989) and acetylene (Bédard and Knowles, 1989; Benner et al., 2015) were investigated for their ability to inhibit methane oxidation.

Partial MMO inhibition and bentazone removal (PIB). We investigated how partial inhibition of methane oxidation by acetylene affected bentazone removal, comparing removal in partially inhibited and active microcosms.

Complete MMO inhibition and bentazone removal (CIB). We investigated how complete inhibition of MMO by acetylene affected bentazone removal, comparing removal in completely inhibited and active microcosms. Concurrently, we studied how different bentazone concentrations affected the methane oxidation. 
This is a Post Print of the article: Hedegaard et al. (2018), Water Research.

https://doi.org/10.1016/j.watres.2017.10.073

\begin{tabular}{|c|c|c|c|c|c|}
\hline Experiment & PM & IMMO & PIB & \multicolumn{2}{|c|}{ CIB } \\
\hline $\begin{array}{l}\text { Number active } \\
\text { microcosms }\end{array}$ & $6^{*}$ & 2 & 3 & $\frac{\text { High conc. }}{3}$ & $\frac{\text { Low conc. }}{3}$ \\
\hline $\begin{array}{l}\text { Number inhibited } \\
\text { microcosms }\end{array}$ & - & 4 & 2 & 3 & 3 \\
\hline $\begin{array}{l}\text { Biomass and carrier } \\
\text { material }(\mathrm{g})\end{array}$ & 10 & 10 & 20 & 10 & 10 \\
\hline Bentazone (mg/L) & $1.7-1.8$ & - & 0.8-0.9 & 0.7 & - \\
\hline${ }^{14} \mathrm{C}$-bentazone $(\mu \mathrm{g} / \mathrm{L})$ & - & - & 1.4 & 1.6 & 1.6 \\
\hline Microcosms with $\mathrm{CH}_{4}$ & $\begin{array}{l}3(\text { Maintained } \\
\left.\text { at } 5 \mathrm{mg} \mathrm{CH}_{4} / \mathrm{L}\right)\end{array}$ & 6 (Initial injection to $5 \mathrm{mg} \mathrm{CH}_{4} / \mathrm{L}$ ) & $\begin{array}{l}5 \text { (initial injection } \\
\text { to } 5 \mathrm{mg} \mathrm{CH}_{4} / \mathrm{L} \text { ) }\end{array}$ & \multicolumn{2}{|c|}{$\begin{array}{l}12 \text { (Maintained at } 5 \mathrm{mg} \\
\mathrm{CH}_{4} / \mathrm{L} \text { ) }\end{array}$} \\
\hline Microcosms w/o CH & 3 & - & - & \multicolumn{2}{|c|}{ - } \\
\hline Inhibitor & - & $\begin{array}{c}\text { ATU: } 1.2 \mathrm{mg} / \mathrm{L} \text { and } 2.4 \mathrm{mg} / \mathrm{L} \\
\text { Acetylene: } 16 \mathrm{mg} / \mathrm{L} \text { and } 26 \mathrm{mg} / \mathrm{L}\end{array}$ & $\begin{array}{l}\text { Acetylene: } 16 \mathrm{mg} / \mathrm{L} \\
\text { and } 26 \mathrm{mg} / \mathrm{L}\end{array}$ & \multicolumn{2}{|c|}{ Acetylene: $26 \mathrm{mg} / \mathrm{L}$} \\
\hline $\begin{array}{l}\text { Conservation of } \\
\text { bentazone samples }\end{array}$ & Frozen & - & Frozen & \multicolumn{2}{|c|}{ Acetic acid } \\
\hline
\end{tabular}

*Four microcosms analysed by HPLC-DAD - results in Figure 2. Two microcosms analysed by High-res-MS for bentazone and transformation products

To distinguish removal of bentazone from removal of potentially formed transformation products ( $\mathrm{OH}$-bentazone), we primarily used high concentrations (1 $\mathrm{mg} / \mathrm{L}$ ) of bentazone, measured by High-Performance Liquid Chromatography with Diode-Array Detection (HPLC-DAD). However, due to the sensitivity of this instrument it was not possible to detect low concentrations $(1 \mu \mathrm{g} / \mathrm{L})$ and experiments with ${ }^{14} \mathrm{C}$-bentazone were included to investigate removal at low concentrations. Also, experiments were conducted in microcosms and lasted up to 21 days.

\subsection{Microcosms and sampling}

We collected the methanotrophic culture from the methane-fed column reactors with an autoclaved spoon and homogenized the sample. Within two hours, we transferred 10-20 g biomass and carrier material ( $\mathrm{g}_{\mathrm{b} \& \mathrm{c}}$ ) and $100 \mathrm{~mL}$ of the non-chlorinated tap water that fed the column reactors to $300 \mathrm{~mL}$ serum bottles (microcosms) which had been acid-washed and heated to $555^{\circ} \mathrm{C}$ for at least 12 hours. Microcosms were closed with acid-washed and autoclaved Teflon coated rubber stoppers and aluminium lids and $51 \mathrm{~mL}$ of the headspace were replaced by methane with a syringe with a needle through the rubber stopper. We incubated the microcosms at room temperature (18$23^{\circ} \mathrm{C}$ ) in an orbital shaker $(120-140 \mathrm{rpm})$ and $\mathrm{pH}$ remained at 7.5-8 during the experiments. Methane oxidation was monitored in all microcosms during the initial 34 days (except in experiment PM) to verify similar methanotrophic activity before addition of inhibitor and bentazone (see concentrations in Table 1).

In order to identify an appropriate inhibitor that stops the methane oxidation completely, methane, allylthiourea (ATU) or acetylene were added to microcosms that 
This is a Post Print of the article: Hedegaard et al. (2018), Water Research. https://doi.org/10.1016/j.watres.2017.10.073

oxidized methane at a similar rate for the first 3.7 days (Figure S1). Acetylene successfully inhibited methane oxidation for more than eight days, while ATU only inhibited the methane oxidation for approx. three days (Figure S1). Thus, acetylene $(26 \mathrm{mg} / \mathrm{L})$ was chosen as inhibitor in all subsequent experiments.

To monitor aqueous bentazone concentration over time, water samples were collected with a syringe using a needle that was inserted through the rubber stopper. The collected water samples $(5 \mathrm{~mL})$ were replaced by $5 \mathrm{~mL}$ pure oxygen. The water samples were filtered through a $0.22 \mu \mathrm{m}$ Nylon GF filter (Frisenette Aps, Q-max ${ }^{\circledR}$ GPF Syringe Filters, diameter $25 \mathrm{~mm}$ ) and samples $(2-3 \mathrm{~mL})$ were analysed for ${ }^{14} \mathrm{C}$ bentazone while the remaining fraction was measured for bentazone concentration by HPLC-DAD or high-resolution mass spectrometry (HRMS) (see below).

Methane and pure oxygen were added at least every fourth day in PM and PIB experiments by replacing a volume of the headspace (typically $60 \mathrm{~mL}$ ) by a mixture of $2: 1 \mathrm{v} / \mathrm{v}$ of pure oxygen and methane (as stoichiometrically required for the oxidation of methane).

When methane concentration in water phase got below $4 \mathrm{mg} / \mathrm{L}$ in the CIB experiment, methane was either added directly or microcosms were opened and flushed with air for at least one hour, subsequently closed and methane and pure oxygen (2:1 v/v of pure oxygen and methane) were added to the headspace.

Neither methane nor oxygen was added to the inhibited microcosms after acetylene was added.

\subsection{Methane and oxygen measurements}

A sample of $50 \mu \mathrm{L}$ was collected from headspace of the microcosms and analysed immediately on GC-FID (see SI for details).

Aqueous oxygen saturation was monitored during the experiment by OxygenSensitive Minisensors and a fiber optic oxygen meter (Fibox 3, Loligo Systems ApS). The measurement was based on a two point calibration and the limit of detection was $0.01 \%$, and the objective of the measurement was primarily to document aerobic conditions during the experiment. Thus, in some cases oxygen was measured before addition of oxygen.

\subsection{Bentazone measurements by High-Performance Liquid Chromatography with Diode-Array Detection (HPLC-DAD)}

Water samples were either immediately frozen or preserved with acetic acid (final concentration of $0.1 \mathrm{M}$ ) until analysis within a few days; investigations showed no difference between the two different ways of storage. The samples which had been stored frozen were acidified by acetic acid prior to injection on an Ultimate 3000 HPLC-DAD system (Thermo Scientific) (see SI). Presented graphs and removal rates are based on either frozen samples or samples preserved in acetic acid. 
This is a Post Print of the article: Hedegaard et al. (2018), Water Research. https://doi.org/10.1016/j.watres.2017.10.073

\section{$2.6{ }^{14} \mathrm{C}$-Carbonyl-bentazone measurements}

The ${ }^{14} \mathrm{C}$-activity of bentazone in the water phase and the produced ${ }^{14} \mathrm{CO}_{2}$ from bentazone mineralization were quantified by a double vial system, where produced ${ }^{14} \mathrm{CO}_{2}$ in the water was stripped off by acidification and captured by a base trap $(1 \mathrm{~mL}$ $2 \mathrm{M} \mathrm{NaOH}$ ) (Janniche et al., 2010). The ${ }^{14} \mathrm{C}$-activity was quantified using a liquid scintillation counter (Hidex 300 SL, 1414 Liquid Scintillation Counter, MikroWin 2000 software). The concentration at a given sampling time was expressed as a fraction of the initial concentration and corrected for the removed mass during sampling (given as $\left.{ }^{14} \mathrm{C} /{ }^{14} \mathrm{C}_{0}(\%)\right)$.

\subsection{Analysis of bentazone transformation products by high-resolution mass spectrometry}

Water samples were analysed for transformation products by high-resolution mass spectrometry (HRMS) using an Orbitrap Velos Fourier Transform Mass Spectrometer coupled to an Accela HPLC system (all Thermo Scientific, Bremen, Germany) with an electrospray ionization (ESI) interface (see SI).

\subsection{Estimation of methanotroph abundance using Real-time quantitative PCR $(q P C R)$}

After two weeks and again after one year of operation the methanotrophic enrichment culture was collected from three column reactors and manually blended. The material was drained and stored at $-20^{\circ} \mathrm{C}$. At the end of the CIB experiments, $2 \mathrm{~mL}$ samples containing both water and biomass were taken from the microcosms and after centrifugation the water phase was discharged and the biomass was stored concentrated as a pellet at $-80^{\circ} \mathrm{C}$ until analysis. All bacteria (Eubacteria - targeting the $16 \mathrm{~S}$ rRNA gene) and methanotrophs (targeting $p m o A$ ) were quantified by real-time quantitative PCR (qPCR) (see SI). Microbial abundances were calculated under the assumption of an average of two copies of 16S rRNA (Klappenbach, 2001; Lee et al., 2006) or pmoA (Semrau et al., 1995; Stolyar et al., 1999) genes per genome (cell) and were subsequently converted to cell densities per mass of filter material (drained wet weight).

\subsection{Chemicals}

Allylthiourea (ATU) and cold bentazone were dissolved in sterile MilliQ water. Mineralization and removal at very low concentrations $(1-2 \mu \mathrm{g} / \mathrm{L})$ were investigated by [carbonyl $\left.-{ }^{14} \mathrm{C}\right]$-bentazone (Izotop, Institute of Isotopes Co., Ltd., Hungary) in two experiments (Table 1). The radiochemical purity of [carbonyl- ${ }^{14} \mathrm{C}$ ]-bentazone was $100 \%$ (chemical purity $99.77 \%$ ) according to the manufacturer and a stock solution was prepared in sterile MilliQ water. Bentazone (chemical purity $99.1 \%$, Dr. Ehrenstorfer $\mathrm{GmbH}$ ), 6-OH-bentazone (chemical purity 97\%, TRC, Toronto Research Chemicals Inc., Ontario, Canada) and 8-OH-bentazone (chemical purity 97\%, TRC, Toronto Research Chemicals Inc., Ontario, Canada) were all dissolved in sterile ultrapure water at least one day prior to the experiment. The concentration was verified 
This is a Post Print of the article: Hedegaard et al. (2018), Water Research.

https://doi.org/10.1016/j.watres.2017.10.073

by HPLC-DAD immediately before the experiment. Acetylene was added from a gas flask (see SI).

\subsection{Statistics}

We used the statistical software GraphPad Prism 5 for data treatment.

\section{Results and discussion}

\subsection{Growth of methanotrophic culture}

We successfully enriched methanotrophs in the column reactors: the abundance of methanotrophs increased from $1.04 \times 10^{4}$ cells/g carrier material after two weeks growth to $2.55 \times 10^{7}$ cells/g carrier material after more than one year of enrichment. The fraction of methanotrophs compared to the total number of bacteria increased from $1.7 \%$ after two weeks to $12 \%$ after one year (Figure S2) and was larger in column reactors and microcosms than in the full-scale rapid sand filters $\left(8.5 \times 10^{5}\right.$ cells/g carrier material, $1.3 \%)$.

\subsection{Effect of methane on bentazone removal (PM)}

The methanotrophic enrichment demonstrated a bentazone removal rate of 42-75 $\rho$ moles $/ \mathrm{h} / \mathrm{g}_{\mathrm{b} \& \mathrm{c}}$ during the experiment 'Presence of methane' (PM) (Figure 2). Hence, up to $53 \%$ of the initial mass of bentazone was removed after 21 days in microcosms with $5 \mathrm{mg} / \mathrm{L}$ methane, while only $31 \%$ was removed in microcosms without methane (Figure 2). This was confirmed in a replicate experiment showing a bentazone removal rate of $116 \rho$ moles $/ \mathrm{h} / \mathrm{g}_{\mathrm{b} \& \mathrm{c}}$ in presence of methane and $35 \mathrm{\rho moles} / \mathrm{h} / \mathrm{g}_{\mathrm{b} \& \mathrm{c}}$ in absence of methane during the first seven days (data not shown). 


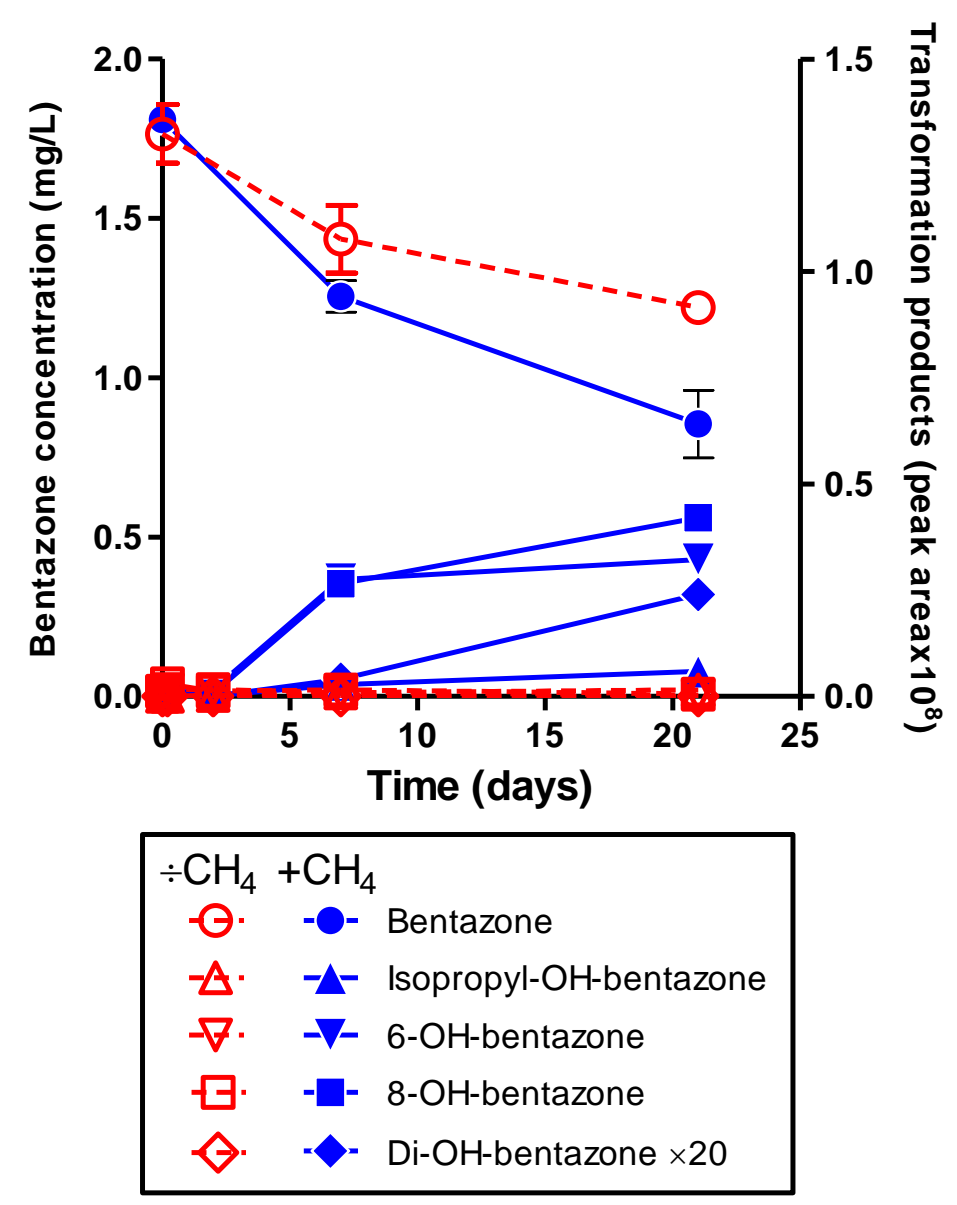

Fig. 2 Effect of methane on removal of bentazone and formation of bentazone transformation products by the methanotrophic enrichment culture. Bentazone measured by HPLC-DAD (duplicates) and isopropyl-OH-, 6-OH-, 8-OH-bentazone and di-OH-bentazone measured by High-res-MS as peak areas (single microcosm). Microcosms with $10 \mathrm{~g}$ methane enriched biomass and carrier material and $100 \mathrm{~mL}$ tap water with methane (approx. $5 \mathrm{mg} / \mathrm{L}$ in the water) or without methane.

\subsection{Inhibition of methane oxidation and its effect on bentazone removal (CIB)}

To investigate how bentazone removal depended on methane oxidation, we inhibited methane oxidation with acetylene. Acetylene functions as a suicide substrate towards MMO and causes a rapid and irreversible self-inactivation by formation of reactive intermediates which binds to the active site of the hydroxylase subunit (component A) (Prior and Dalton, 1985; Sullivan and Chase, 1996).

Before acetylene and bentazone were added, all microcosms demonstrated similar methane consumption rates: 1.3-2.0 $\mu$ mole methane $/ \mathrm{h} / \mathrm{g}_{\mathrm{b} \& \mathrm{c}}$ (Figure $3 \mathrm{~B}$, time period: 5 to -1 days), in CIB experiments. Acetylene addition (time: -1 day) successfully stopped methane consumption in the inhibited microcosms (Figure 3B). Addition of acetylene also stopped oxygen consumption in the inhibited microcosms, while the 
This is a Post Print of the article: Hedegaard et al. (2018), Water Research.

https://doi.org/10.1016/j.watres.2017.10.073

active microcosms continuously consumed oxygen (Figure 3D). Other oxygenconsuming metabolic activity was therefore negligible.
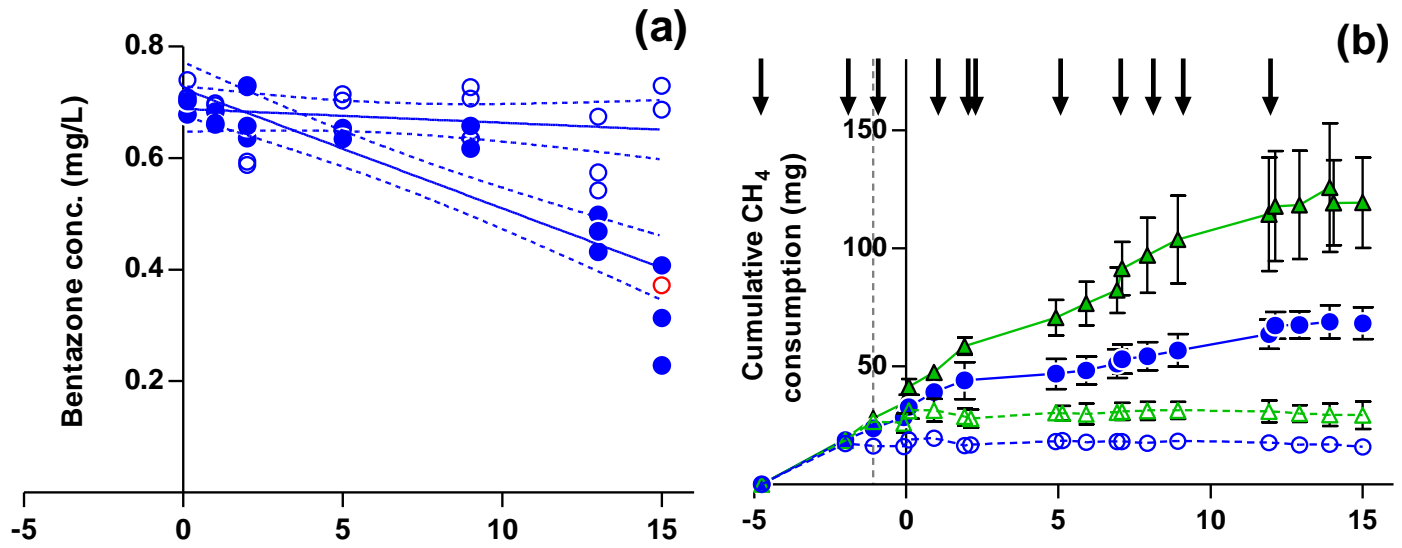

(c)
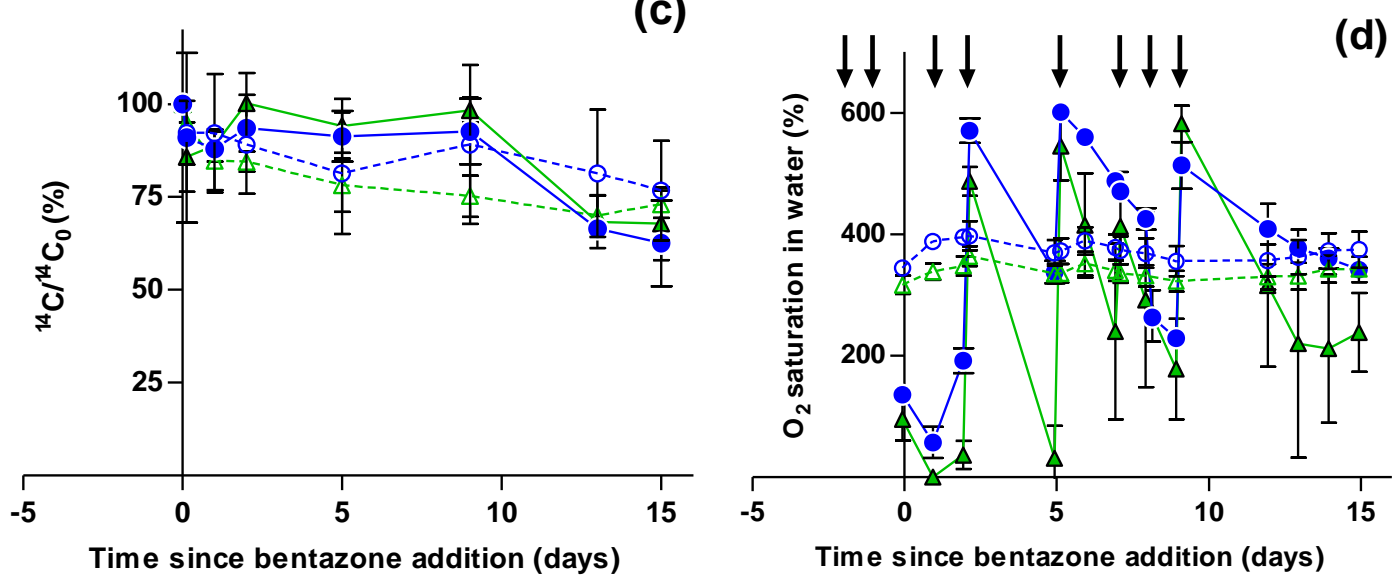

$$
\begin{array}{ll}
\triangle 1 \mu \mathrm{g} / \mathrm{L} \text { Bentazone } & -\triangle-1 \mu \mathrm{g} / \mathrm{L} \text { Bentazone + Acetylene } \\
-1 \mathrm{mg} / \mathrm{L} \text { Bentazone } & -\Theta-1 \mathrm{mg} / \mathrm{L} \text { Bentazone + Acetylene } \\
\downarrow \text { Addition of } \mathrm{CH}_{4} \text { and } \mathrm{O}_{2} \text { to active microcosms }
\end{array}
$$

Fig. 3 Bentazone removal, methane and oxygen consumption by the methanotrophic enrichment culture. Removal in active microcosms and microcosms with acetylene (both in triplicates) with $10 \mathrm{~g}$ biomass and carrier material, $100 \mathrm{~mL}$ tap water, approx. $5 \mathrm{mg} / \mathrm{L}$ methane and bentazone at high $(1 \mathrm{mg} / \mathrm{L})$ and low $(1 \mu \mathrm{g} / \mathrm{L})$ concentrations. A) Bentazone concentration measured by HPLC-DAD, linear regression curves (full lines) with 95\% confidence intervals (dotted lines). The red dot marks an outlier (not included in the regression). B) Methane consumption. C) ${ }^{14} \mathrm{C}$-bentazone concentration given as percentage of initial concentration. D) \% oxygen saturation in the water phase. Acetylene $(26 \mathrm{mg} / \mathrm{L})$ was added to inhibited microcosms (grey dotted line at time -1 day) prior to bentazone addition (time 0 ). When $\mathrm{C}_{\mathrm{w}, \mathrm{CH} 4}<4$ $\mathrm{mg} / \mathrm{L}$ methane was either added directly or microcosms were flushed with air, and methane and oxygen were added subsequently $\left(2: 1 \mathrm{vo}_{\mathrm{O}} / \mathrm{v}_{\mathrm{CH} 4}\right)$. 
This is a Post Print of the article: Hedegaard et al. (2018), Water Research. https://doi.org/10.1016/j.watres.2017.10.073

At day 0 bentazone was added to all microcosms (experiment CIB). The methane consumption rate clearly followed a linear trend (Figure 3B and Table 2), and, assuming that bentazone removal also depended on the activity of the MMO, a simple linear regression model (removed mass versus time) was applied to describe bentazone removal (Figure 3A and Table 2). In active microcosms the bentazone removal rate was $37 \pm 5.0 \rho \mathrm{mole} / \mathrm{h} / \mathrm{g}_{\mathrm{b} \& \mathrm{c}}\left(\mathrm{r}^{2}=0.77\right)$, and was thus significantly larger than in the inhibited microcosms $(\mathrm{P}<0.0001$, including both samples preserved frozen and in acetic acid; even when the outlier in the inhibited microcosms at day 15 is included $\mathrm{P}=0.00084)$ in which the removal rate, $4.3 \pm 4.2 \rho \mathrm{mole} / \mathrm{h} / \mathrm{g}_{\mathrm{b} \& \mathrm{c}}\left(\mathrm{r}^{2}=0.06\right)$, was not significantly different from zero (Figure $3 \mathrm{~A}$ ).

\begin{tabular}{|c|c|c|c|c|c|}
\hline Exp. & Inhibition & $\begin{array}{l}\text { Time } \\
\text { (days) }\end{array}$ & $\begin{array}{c}\text { Bentazone consumption, } \\
\text { rBentazone } \\
\left(\mathrm{pmole} / \mathrm{h} / \mathrm{g}_{\mathrm{b} \& \mathrm{c}}\right)\end{array}$ & $\begin{array}{c}\text { Methane consumption, } \\
\text { rch4 } \\
\left(\mathrm{nmole} / \mathrm{h} / \mathrm{g}_{\mathrm{b} \& \mathrm{c}}\right)\end{array}$ & 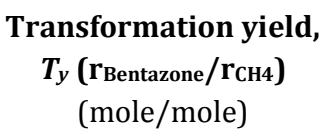 \\
\hline \multirow{2}{*}{ PIB } & - & 1 & $270 \pm 60, n=12$ & $2000 \pm 200, n=12$ & $1.4 \times 10^{-4}$ \\
\hline & Partially & 1 & $150 \pm 50, n=12$ & $880 \pm 280, n=9$ & $1.7 \times 10^{-4}$ \\
\hline \multirow{2}{*}{ CIB } & - & 15 & $37 \pm 5.0, n=21$ & $610 \pm 50, n=42$ & $0.6 \times 10^{-4}$ \\
\hline & + & 15 & $4.3 \pm 4.2, \mathrm{n}=20$ & Not detected, $n=45$ & $\infty$ \\
\hline
\end{tabular}

A similar abundance of $p m o A$ genes in all microcosms at the end of the experiment CIB confirmed that the difference in methane consumption and bentazone removal between active and inhibited microcosms was not caused by a difference in the abundance of methanotrophs (Figure S2). Hence, addition of acetylene inhibited both methane oxidation and bentazone removal.

\subsection{Transformation yield of bentazone versus methane removal (PIB and CIB)}

The transformation yield, $T_{y, B T Z / C H 4}$, expresses the bentazone (BTZ) removal rate over the methane removal rate. Removal rates were estimated by linear regression models (removed mass of bentazone or methane per time) at three different methane consumption rates and in two independent experiments (Table 2). At similar concentrations of bentazone $(0.7-0.9 \mathrm{mg} / \mathrm{L}$ ) and methane (approx. $5 \mathrm{mg} / \mathrm{L}$ ) the consumption rate of bentazone followed the consumption rate of methane, and e.g. in the experiment 'Partial MMO inhibition and bentazone removal' (PIB) the lower methane consumption rate in the partially inhibited control (compared to active microcosms) was accompanied by a correspondingly slow bentazone removal (Table 2 ). Thus, the transformation yield, $T_{y, B T Z / C H 4}$, varied between $0.6 \times 10^{-4}$ and $1.7 \times 10^{-4}$ mole $_{\mathrm{BTz}} /$ mole $_{\mathrm{CH} 4}$ for active and partially inhibited microcosms in two independent experiments (Table 2). The transformation yields were thus within a factor three across 
This is a Post Print of the article: Hedegaard et al. (2018), Water Research. https://doi.org/10.1016/j.watres.2017.10.073

our experiments (Table 2), which strongly indicates an association between methane monooxygenase activity and bentazone removal.

This measured transformation yield was in the low range of values reported for the trace pollutants (TC) chlorinated aliphatic hydrocarbons $\left(2.2 \times 10^{-4}\right.$ to $6.3 \times 10^{-1}$ mole $\mathrm{TC}_{\mathrm{mole}} \mathrm{m}_{4}$ ) (Table 3 ). However, the ratio $C_{B T Z / C H 4}$, between the secondary substrate, bentazone, and the primary substrate, methane, was close to environmentally-relevant conditions in the present study $\left(9.6 \times 10^{-3}\right.$ mole $\left._{\mathrm{BTZ}} / \mathrm{mole}_{\mathrm{CH} 4}\right)$ but low compared to previous studies: $1.1 \times 10^{-2}$ to 6.5 mole $_{\mathrm{TC}} / \mathrm{mole}_{\mathrm{CH} 4}$ (Table 3). The large difference in the relative abundance of primary and secondary substrates can make the comparison of the transformation yields between different studies of no relevance.

Assuming a constant number of active enzymes in our experiments (as indicated by linear consumption of methane with time), we expect that an increased abundance of a secondary substrate relative to the primary would result in an increased transformation yield of secondary compared to primary substrate. To establish a metric independent of the substrates relative concentrations, we suggest to normalize the transformation yield with respect to the concentration ratio between secondary and primary substrate, $T_{y}{ }^{*}$, CH4/TC:

$$
T_{y}{ }^{*} \text { CH } 4 / T C=T_{y, T C / C H 4}{ }^{-1} / C_{T C / C H} 4^{-1}=T_{y, C H 4 / T C} / C_{C H 4 / T C}
$$

Where $T_{y}{ }^{*}, C H 4 / T C$ is the $\mathrm{CH}_{4} / \mathrm{TC}$-normalized transformation yield of $\mathrm{MMO}$ for oxidizing methane over the trace contaminant, $T_{y, T C / C H 4}$ is the transformation yield of the trace contaminant relative to methane and $C_{T C / C H 4}$ is the concentration ratio between secondary and primary substrates. From reported data we calculated the $\mathrm{CH}_{4} / \mathrm{TC}$-normalized transformation yields, $T_{y}{ }^{*}, \mathrm{CH} 4 / \mathrm{TC}$, ranging from 3 to 400 , and $T_{y}{ }^{*}$,CH4/BTZ in our study (58-158) was thus within this range (Table 3). Hence, the $\mathrm{CH}_{4} / \mathrm{TC}$ normalized transformation yields show that, in a situation with an even presence of bentazone and $\mathrm{CH}_{4}$-molecules, bentazone would at maximum be oxidized in 1 out of 58 incidences. Similar magnitude in the preference of MMO for methane over other trace contaminants, indicates that the removal mechanism of bentazone is similar to co-metabolic degradation of other trace contaminants by MMO. 
This is a Post Print of the article: Hedegaard et al. (2018), Water Research.

https://doi.org/10.1016/j.watres.2017.10.073

\begin{tabular}{|c|c|c|c|c|c|c|c|}
\hline \multirow[t]{2}{*}{ Culture } & \multirow{2}{*}{$\begin{array}{l}\text { Trace } \\
\text { contaminant }\end{array}$} & \multirow{2}{*}{$\begin{array}{c}\text { Max. transformation } \\
\text { yield } \\
\boldsymbol{T}_{\boldsymbol{y}}\left(\mathbf{r}_{\mathrm{TC}} / \mathbf{r}_{\mathrm{CH} 4}\right) \\
\left(\mathrm{mole}_{\mathrm{TC}} / \mathrm{mole}_{\mathrm{CH} 4}\right) \\
\end{array}$} & \multicolumn{2}{|c|}{ Max. aqueous conc. of } & \multirow{2}{*}{$\begin{array}{c}\text { Conc. ratio } \\
\text { C }_{T C / \mathrm{CH}^{a}} \\
\left(\mathrm{~mole}_{\mathrm{TC}} / \mathrm{mole}_{\mathrm{CH} 4}\right)\end{array}$} & \multirow{2}{*}{$\begin{array}{c}\text { Normalized } \\
\text { transformation yield } \\
T_{y}^{*}, C H 4 / T C^{a}\left(T_{y, C H 4 / T C} / \mathrm{C}_{C H 4 / T C}\right) \\
-\end{array}$} & \multirow[b]{2}{*}{ Reference } \\
\hline & & & $\begin{array}{c}\mathbf{C H}_{4} \\
(\mu \mathrm{M})\end{array}$ & $\begin{array}{c}\text { Trace contaminant } \\
(\mu \mathrm{M})\end{array}$ & & & \\
\hline \multirow{2}{*}{$\begin{array}{l}\text { Mixed } \\
\text { cultures }\end{array}$} & Bentazone & $1.7 \times 10^{-4}$ & 312 & 3.0 & $9.6 \times 10^{-3}$ & 58 & Present study \\
\hline & TCE & $4.9 \times 10^{-3}$ & 349 & 43 & $1.2 \times 10^{-1}$ & 25 & Smith and McCarty (1997) \\
\hline \multirow{14}{*}{$\begin{array}{l}\text { Pure } \\
\text { cultures }\end{array}$} & TCE & $5.3 \times 10^{-3}$ & 75 & 150 & 2.0 & 377 & Fennell et al. (1993) \\
\hline & TCE & $7.5 \times 10^{-3}$ & 60 & 150 & 2.5 & 333 & Phelps et al. (1990) \\
\hline & VC & $6.6 \times 10^{-3}$ & 6.3 & 2.2 & $3.5 \times 10^{-1}$ & 53 & Nelson and Jewell (1993) \\
\hline & TCE & $1.9 \times 10^{-3}$ & 50 & 13 & $2.6 \times 10^{-1}$ & 137 & Anderson and Mccarty (1997b) \\
\hline & TCE & $4.1 \times 10^{-3}$ & 4.7 & 7 & 1.5 & 363 & Arvin (1991) \\
\hline & 1,1-DCE & $2.2 \times 10^{-4}$ & 50 & 0.56 & $1.1 \times 10^{-2}$ & 51 & Anderson and Mccarty (1997b) \\
\hline & c-DCE & $5.8 \times 10^{-2}$ & 30 & 86 & 2.9 & 49 & Anderson and Mccarty (1997b) \\
\hline & c-DCE & $2.5 \times 10^{-2}$ & 4.7 & 28 & 6.0 & 238 & Arvin (1991) \\
\hline & $\mathrm{t}-\mathrm{DCE}$ & $5.7 \times 10^{-1}$ & 30 & 160 & 5.3 & 9 & Anderson and Mccarty (1997b) \\
\hline & $\mathrm{t}-\mathrm{DCE}$ & $3.9 \times 10^{-2}$ & 4.7 & 0.6 & $1.3 \times 10^{-1}$ & 3 & Arvin (1991) \\
\hline & $\mathrm{t}-\mathrm{DCE}$ & $6.3 \times 10^{-2}$ & 40 & 100 & 2.5 & 40 & Janssen et al. (1988) \\
\hline & $\mathrm{t}-\mathrm{DCE}$ & $6.3 \times 10^{-1}$ & 3.1 & 20 & 6.5 & 10 & Anderson and Mccarty (1997a) \\
\hline & VC & $2.6 \times 10^{-1}$ & 205 & 208 & 1.0 & 4 & Dolan and McCarty (1995) \\
\hline & VC & $2.0 \times 10^{-1}$ & 30 & 17 & $5.7 \times 10^{-1}$ & 3 & Anderson and Mccarty (1997b) \\
\hline
\end{tabular}

${ }^{\mathrm{a}}$ Calculated from data in given reference 
This is a Post Print of the article: Hedegaard et al. (2018), Water Research. https://doi.org/10.1016/j.watres.2017.10.073

\subsection{Effect of bentazone on the methane oxidation (CIB)}

After bentazone addition at day 0 in the CIB experiment, the methane consumption was $1.5 \mu$ mole $_{\mathrm{CH} 4} / \mathrm{h} / \mathrm{g}_{\mathrm{b} \& \mathrm{c}}$ in active microcosms at low $(1 \mu \mathrm{g} / \mathrm{L})$ bentazone concentrations, which was similar to before bentazone addition (1.3-2.0 $\mu$ mole $_{\mathrm{CH}} / \mathrm{h} / \mathrm{g}_{\mathrm{b} \& \mathrm{c}}$ in all microcosms and inhibited controls) (Figure 3B). In contrast, in active microcosms at high bentazone concentration $(1 \mathrm{mg} / \mathrm{L})$, methane consumption decreased to $0.6 \mu$ mole $_{\mathrm{CH} 4} / \mathrm{h} / \mathrm{g}_{\mathrm{b} \& \mathrm{c}}$ (Figure $3 \mathrm{~B}$ ). Thus, a high bentazone concentration led to a significantly lower $(\mathrm{P}<0.0001)$ methane consumption rate than a low bentazone concentration, at similar conditions (oxygen and methane concentration, number of methanotrophs and methanotrophs/total bacteria (Figure S2)).

Oxidation of trace pollutants can negatively affect the methane oxidation due to 1) competition for binding to MMO; 2) consumption of reducing equivalents; and 3) toxic effects (Alvarez-Cohen and McCarty, 1991; Semrau et al., 2010). The theoretical upper limit for transformation yields on 1.64 mole $_{\mathrm{TC}} /$ mole $_{\mathrm{CH} 4}$ (Anderson and Mccarty, 1997a) and transformation yields found in literature (Table 3) are much higher than the measured bentazone transformation yields $\left(T_{y, B T Z / C H 4}=0.6 \times 10^{-4}\right.$ to $1.7 \times 10^{-4}$ mole $\left._{\mathrm{BTZ}} / \mathrm{mole}_{\mathrm{CH} 4}\right)$. Therefore the reduced methane oxidation rate at high bentazone concentrations was unlikely only the result of excessive consumption of reducing equivalents. No toxic effects have been reported for bentazone in soil microbial community toxicity tests or in Microtox tests at $2 \mathrm{mg} / \mathrm{L}$, the maximum concentration applied in our study (Allievi et al., 1996; Ruiz et al., 1997). Also the bentazone degradation products 6-OH-bentazone and 8-OH-bentazone are less acute toxic than the parent compound (Kanungo et al., 2012). We posit that the reduced methane consumption at high bentazone concentrations was, in part, due to competitive inhibition of methane oxidation by bentazone. Yet, the decrease in methane consumption was disproportionally high and not consistent with simple competitive inhibition. We speculate additional MMO inactivation caused by accumulation of a toxic bentazone transformation products, as shown for MMO-driven co-metabolic transformation of TCE in previous studies (Semprini et al., 1990; Suttinun et al., 2013). At environmentally relevant bentazone concentrations and bentazone/methane ratios $\left(1 \mu \mathrm{g} / \mathrm{L}, 1.4 \times 10^{-5}\right.$ mole $_{\mathrm{BTz}} /$ mole $\left._{\mathrm{CH}}\right)$, methane oxidation was not affected.

\subsection{Formation of bentazone transformation products (CIB, PIB and PM)}

Quantification of bentazone removal by ${ }^{14} \mathrm{C}$-carbonyl-bentazone only allowed determination of complete removal from the water phase, and, accordingly, a transformation from bentazone to hydroxy-bentazone would not be detected, since the

${ }^{14} \mathrm{C}$-carbonyl-group would still be present in the transformation products (Figure 1). During the experiments there was no significantly different loss of ${ }^{14} \mathrm{C}$ from the water phase in inhibited and active microcosms (Figure 3B), and no ${ }^{14} \mathrm{CO}_{2}$ from bentazone mineralization was detected (measured in PIB experiment - data not shown). Indicating that bentazone was only transformed and not mineralized by the methanotrophic culture. 
This is a Post Print of the article: Hedegaard et al. (2018), Water Research. https://doi.org/10.1016/j.watres.2017.10.073

Measurements by HRMS confirmed an accumulation of four bentazone transformation products (6-OH-bentazone, 8-OH-bentazone, isopropyl-OH-bentazone and dihydroxy-bentazone) in the water phase during bentazone degradation by the methanotrophic enrichment culture (Figure 2; Figure 1; Table S1 in SI). The chemical structures of 6-OH-bentazone and 8-OH-bentazone were confirmed by comparison with commercially available reference standards. Even though no reference standard was available for isopropyl-OH-bentazone (IUPAC: 3-(1-hydroxypropan-2-yl)-1Hbenzo[c][2,1,3]thiadiazin-4(3H)-one-2,2-dioxide), hydroxylation of the isopropyl moiety was clearly indicated by cleavage of $\mathrm{C}_{3} \mathrm{H}_{6} \mathrm{O}$ instead of $\mathrm{C}_{3} \mathrm{H}_{6}$ as in bentazone and the ring hydroxylated TPs (Table S1 in SI). A dihydroxylated bentazone TP (di$\mathrm{OH}$-bentazone) was also detected based on the exact mass determinations, however, concentrations were too low to obtain fragmentation data from $\mathrm{MS}^{2}$ experiments and thus, it was not possible to determine the exact position of the hydroxylation. After 21 days, four times more isopropyl-OH-, 132 times more 6-OH- and 85 times more 8$\mathrm{OH}$-bentazone were observed in presence versus absence of methane. In addition, formation of di-OH-bentazone was only observed in the presence of methane (Figure 2; Figure 1).

The two substituents on the aromatic ring of bentazone are a strongly electron donating secondary amine and an electron withdrawing ketone-group (McMurry and Simanek, 2007), both substituents are directing oxidation towards the 6-OH- (para-position with respect to the donating amine group) and 8-OH- (ortho-) position of bentazone, which were both formed during degradation of bentazone in the methanotrophic culture. Methanotrophic oxidation is typically regioselective towards the para-position of monosubstituted aromatic compounds (Anthony, 1986; Dalton and Leak, 1985; Lindner et al., 2000). Our results indicate a similar formation of $6-\mathrm{OH}-$ and $8-\mathrm{OH}-$ bentazone by the methanotrophic culture (Figure 1), though presence of methane had the largest impact (concentration increased 132 times) on the formation of 6-OHbentazone (para-position). This is in contrast to field soils where primary 8-OHbentazone was formed (Knauber et al., 2000), indicating the involvement of an additional transformation process. This was also indicated by the formation of isopropyl-OH- and di-OH-bentazone in our study, which so far has not been reported as a transformation product (Huber and Otto, 1994).

In fresh field soils, 6-OH- and 8-OH-bentazone were further metabolised faster than they were formed from degradation of bentazone (Huber and Otto, 1994; Knauber et al., 2000). The accumulation of $\mathrm{OH}$-transformation products in the water phase illustrated that the methanotrophic enrichment culture only performed the primary transformation step and that other metabolic pathways capable of metabolizing 6-OHand 8-OH-bentazone were not sufficiently abundant to substantially degrade these transformation products. 
This is a Post Print of the article: Hedegaard et al. (2018), Water Research. https://doi.org/10.1016/j.watres.2017.10.073

It is commonly accepted that sMMO oxidizes aromatic rings, while pMMO cannot attack these structures (Burrows et al., 1984; Semrau et al., 2010). The acetylene concentrations applied in our investigations, $16 \mathrm{mg} / \mathrm{L}(614 \mu \mathrm{M})$ and $26 \mathrm{mg} / \mathrm{L}(998$ $\mu \mathrm{M})$, are reported not to completely inhibit pMMO, but are reported to inhibit sMMO (Lontoh et al., 2000). Hence, the complete inhibition of the methane oxidation at both $16 \mathrm{mg} / \mathrm{L}(614 \mu \mathrm{M})$ and $26 \mathrm{mg} / \mathrm{L}(998 \mu \mathrm{M})$ (Figure S1) supports the involvement of sMMO in bentazone degradation.

\section{Conclusion}

We investigated the first step in the transformation of bentazone - the biological hydroxylation - and provided a suite of evidence supporting that bentazone can be cometabolically transformed to hydroxy-bentazone transformation products by a methanotrophic culture. This conclusion is based on the following lines of evidence:

- Bentazone was removed from the water phase in contact with methanotrophic culture enriched from a rapid sand filter.

- The presence of methane stimulated the removal rate of bentazone.

- Inhibiting the methane oxidation by acetylene also halted bentazone removal.

- The $\mathrm{CH}_{4} / \mathrm{TC}$-normalized transformation yield, $T_{y}{ }^{*}{ }{ }_{C H} / \mathrm{B} T \mathrm{BZ}$, for bentazone ranged from 58 to 158 which is comparable to $\mathrm{CH}_{4} / \mathrm{TC}$-normalized transformation yields of methanotrophic co-metabolism calculated from the literature (3-400).

- The methane consumption rate was significantly lower at high bentazone concentrations $(1 \mathrm{mg} / \mathrm{L})$ than at low concentrations $(1 \mu \mathrm{g} / \mathrm{L})$, which indicated oneway competitive inhibition of bentazone towards methane.

- Presence of methane stimulated formation of hydroxylated bentazone transformation products.

Even though the experiments were conducted with a long term methanotrophic enrichment culture, the enrichment was still a complex community containing many non-methanotrophs. Therefore, obtaining a full enzymatic proof of the hydroxylation of bentazone by MMO would require further studies including pure cultures of methanotrophs.

\section{Acknowledgements}

This research was partly financed by the Grundfos Prize. The authors thank the staff at Sjæls $\varnothing$ waterworks, Nordvand A/S, for help with filter sand collection, Aikaterini Papadopoulou (MIRESOWA project) for constructing the column reactors and Mikael Emil Olsson for technical assistance. We confirm that there are no known conflicts of interest associated with this publication. 
This is a Post Print of the article: Hedegaard et al. (2018), Water Research.

https://doi.org/10.1016/j.watres.2017.10.073

\section{References}

Albrechtsen, H.J., Mills, M.S., Aamand, J., Bjerg, P.L., 2001. Degradation of herbicides in shallow Danish aquifers: An integrated laboratory and field study, in: Pest Management Science. pp. 341-350. doi:10.1002/ps.305

Alexander, M., 1994. Biodegradation and bioremediation, 2nd ed. Academic Press.

Allievi, L., Gigliotti, C., Salardi, C., Valsecchi, G., Brusa, T., Ferrari, A., 1996. Influence of the herbicide bentazon on soil microbial community. Microbiol. Res. 151, 105-111. doi:10.1016/S0944-5013(96)80064-4

Alvarez-Cohen, L., McCarty, P.L., 1991. Effects of toxicity, aeration, and reductant supply on trichloroethylene transformation by a mixed methanotrophic culture. Appl. Environ. Microbiol. 57, 228-235.

Alvarez-Cohen, L., McCarty, P.L., Boulygina, E., Hanson, R.S., Brusseau, G.A., Tsien, H.C., 1992. Characterization of a methane-utilizing bacterium from a bacterial consortium that rapidly degrades trichloroethylene and chloroform. Appl. Environ. Microbiol. 58, 1886-1893.

Anderson, J.E., Mccarty, P.L., 1997a. Transformation yields of chlorinated ethenes by a methanotrophic mixed culture expressing particulate methane monooxygenase. Appl. Environ. Microbiol. 63, 687-693.

Anderson, J.E., Mccarty, P.L., 1997b. Effect of chlorinated ethenes on S(min) for a methanotrophic mixed culture. Environ. Sci. Technol. 31, 2204-2210. doi:10.1021/es9606687

Anthony, C., 1986. Bacterial Oxidation of Methane and Methanol, Advances in Microbial Physiology. doi:10.1016/S0065-2911(08)60305-7

Arvin, E., 1991. Biodegradation kinetics of chlorinated aliphatic hydrocarbons with methane oxidizing bacteria in an aerobic fixed biofilm reactor. Water Res. 25, 873881. doi:10.1016/0043-1354(91)90168-P

Bédard, C., Knowles, R., 1989. Physiology, biochemistry, and specific inhibitors of $\mathrm{CH} 4, \mathrm{NH} 4+$, and $\mathrm{CO}$ oxidation by methanotrophs and nitrifiers. Microbiol. Rev. 53, 68-84. doi:0146-0749/89/010068-17

Benner, J., De Smet, D., Ho, A., Kerckhof, F.M., Vanhaecke, L., Heylen, K., Boon, N., 2015. Exploring methane-oxidizing communities for the co-metabolic degradation of organic micropollutants. Appl. Microbiol. Biotechnol. 99, 3609-3618. doi:10.1007/s00253-014-6226-1 
This is a Post Print of the article: Hedegaard et al. (2018), Water Research. https://doi.org/10.1016/j.watres.2017.10.073

Benner, J., Helbling, D.E., Kohler, H.E., Wittebol, J., Kaiser, E., Prasse, C., Ternes, T.A., Albers, C.N., Aamand, J., Horemans, B., Springael, D., Walravens, E., Boon, N., 2013. Is biological treatment a viable alternative for micropollutant removal in drinking water treatment processes? Water Res. 47, 5955-5976. doi:10.1016/j.watres.2013.07.015

Boivin, A., Cherrier, R., Perrin-Ganier, C., Schiavon, M., 2004. Time effect on bentazone sorption and degradation in soil. Pest Manag. Sci. 60, 809-814. doi: $10.1002 /$ ps.889

Broholm, M.M., Rügge, K., Tuxen, N., Højberg, A.L., Mosbaek, H., Bjerg, P.L., 2001. Fate of herbicides in a shallow aerobic aquifer: A continuous field injection experiment (Vejen, Denmark). Water Resour. Res. 37, 3163-3176. doi:10.1029/2000WR000002

Burrows, K.J., Cornish, A., Scott, D., Higgins, I.J., 1984. Substrate specificities of the soluble and particulate methane mono-oxygenases of Methylosinus trichosporium OB3b. J. Gen. Microbiol. 130, 3327-3333. doi:10.1099/00221287-130-12-3327

Commission, E., 2017. EU pesticides database [WWW Document]. URL http://ec.europa.eu/food/plant/pesticides/eu-pesticidesdatabase/public/?event=homepage \&language $=\mathrm{EN}$

Dalton, H., Leak, D.J., 1985. Mechanistic studies on the mode of action of methane monooxygenase. Gas Enzymol. 169-186.

Dalton, H., Stirling, D.I., 1982. Co-metabolism. Philos. Trans. R. Soc. London. Ser. B Biol. Sci. 297, 481-496.

Dawas-Massalha, A., Gur-Reznik, S., Lerman, S., Sabbah, I., Dosoretz, C.G., 2014. Co-metabolic oxidation of pharmaceutical compounds by a nitrifying bacterial enrichment. Bioresour. Technol. 167, 336-342. doi:10.1016/j.biortech.2014.06.003

De Wilde, T., Spanoghe, P., Mertens, J., Sniegowksi, K., Ryckeboer, J., Jaeken, P., Springael, D., 2009. Characterizing pesticide sorption and degradation in macro scale biopurification systems using column displacement experiments. Environ. Pollut. 157, 1373-1381. doi:10.1016/j.envpol.2008.11.032

DiSpirito, A.A., Gulledge, J., Shiemke, A.K., Murrell, J.C., Lidstrom, M.E., Krema, C.L., 1991. Trichloroethylene oxidation by the membrane-associated methane monooxygenase in type I, type II and type X methanotrophs. Biodegradation 2, 151164. doi:10.1007/BF00124489

Dolan, M.E., McCarty, P.L., 1995. Small-column microcosm for assessing methanestimulated vinyl chloride transformation in aquifer samples. Environ. Sci. Technol. 29, 1892-1897. doi:10.1021/es00008a005 
This is a Post Print of the article: Hedegaard et al. (2018), Water Research. https://doi.org/10.1016/j.watres.2017.10.073

European Community, 2000. Directive 2000/60/EC of the European Parliament and of the Council of 23 October 2000 establishing a framework for Community action in the field of water policy. Off. J. Eur. Parliam. L327, 1-82. doi:10.1039/ap9842100196

European Union, 2006. Directive 2006/118/EC of the European Parliament and of the council of 12 December 2006 on the protection of groundwater against pollution and deterioration. Off. J. Eur. Union 19, 19-31. doi:http://eur-lex.europa.eu/legalcontent/EN/TXT/?uri=CELEX:32006L0118

Fennell, D.E., Nelson, Y.M., Underhill, S.E., White, T.E., Jewell, W.J., 1993. TCE degradation in a methanotrophic attached???film bioreactor. Biotechnol. Bioeng. 42, 859-872. doi:10.1002/bit.260420711

Forrez, I., Carballa, M., Noppe, H., De Brabander, H., Boon, N., Verstraete, W., 2009. Influence of manganese and ammonium oxidation on the removal of 17??ethinylestradiol (EE2). Water Res. 43, 77-86. doi:10.1016/j.watres.2008.10.006

GEUS \& Energi- Forsynings og Klimaministeriet, 2016. Grundvandsovervågningen 1989 - 2015.Hazen, T.C., Chakraborty, R., Fleming, J.M., Gregory, I.R., Bowman, J.P., Jimenez, L., Zhang, D., Pfiffner, S.M., Brockman, F.J., Sayler, G.S., 2009. Use of gene probes to assess the impact and effectiveness of aerobic in situ bioremediation of TCE. Arch. Microbiol. 191, 221-232. doi:10.1007/s00203-008-0445-8

Hedegaard, M.J., Albrechtsen, H.J., 2014. Microbial pesticide removal in rapid sand filters for drinking water treatment - Potential and kinetics. Water Res. 48, 71-81. doi:10.1016/j.watres.2013.09.024

Helbling, D.E., Johnson, D.R., Honti, M., Fenner, K., 2012. Micropollutant biotransformation kinetics associate with WWTP process parameters and microbial community characteristics. Environ. Sci. Technol. 46, 10579-10588. doi:10.1021/es3019012

Huber, R., Otto, S., 1994. Environmental behavior of bentazon.pdf. Rev. Environ. Contam. andToxicology 137, 111-134.

Iwamoto, T., Nasu, M., 2001. Current bioremediation practice and perspective. J. Biosci. Bioeng. 92, 1-8. doi:10.1016/S1389-1723(01)80190-0

Janniche, G.S., Lindberg, E., Mouvet, C., Albrechtsen, H.J., 2010. Mineralization of isoproturon, mecoprop and acetochlor in a deep unsaturated limestone and sandy aquifer. Chemosphere 81, 823-831. doi:10.1016/j.chemosphere.2010.08.023

Janssen, D.B., Grobben, G., Hoekstra, R., Oldenhuis, R., Witholt, B., 1988. Degradation of trans-1,2-dichloroethene by mixed and pure cultures of methanotrophic bacteria. Appl. Microbiol. Biotechnol. 29, 392-399. doi:10.1007/BF00265825 
This is a Post Print of the article: Hedegaard et al. (2018), Water Research.

https://doi.org/10.1016/j.watres.2017.10.073

Jiang, H., Chen, Y., Jiang, P., Zhang, C., Smith, T.J., Murrell, J.C., Xing, X.-H., 2010. Methanotrophs: Multifunctional bacteria with promising applications in environmental bioengineering. Biochem. Eng. J. 49, 277-288. doi:10.1016/j.bej.2010.01.003

Kanungo, D., Dellarco, V., Davies, L., 2012. Bentazone. World Heal. Organ. 4, 3198.

Klappenbach, J.A., 2001. rrndb: the Ribosomal RNA Operon Copy Number Database. Nucleic Acids Res. 29, 181-184. doi:10.1093/nar/29.1.181

Knauber, W.R., Krotzky, A.J., Schink, B., 2000. Microbial metabolism and further fate of bentazon in soil. Environ. Sci. Technol. 34, 598-603. doi:10.1021/es990426h

Lee, C., Kim, J., Shin, S.G., Hwang, S., 2006. Absolute and relative QPCR quantification of plasmid copy number in Escherichia coli. J. Biotechnol. 123, 273280. doi:10.1016/j.jbiotec.2005.11.014

Lindner, A., Adriaens, P., Semrau, J., 2000. Transformation of ortho-substituted biphenyls by Methylosinus trichosporium \{OB3b: substituent effects on oxidation kinetics and product formation. Arch. Microbiol. 174, 35-41. doi:10.1007/s002030000170

Lontoh, S., Dispirito, A.A., Krema, C.L., Whittaker, M.R., Hooper, A.B., Semrau, J.D., 2000. Differential inhibition in vivo of ammonia monooxygenase, soluble methane monooxygenase and membrane-associated methane monooxygenase by phenylacetylene. Environ. Microbiol. 2, 485-494. doi:10.1046/j.14622920.2000.00130.x

McMurry, J., Simanek, E., 2007. Fundamentals of Organic Chemistry, sixth edit. ed. Thomson Brooks/Cole.

Nelson, Y.M., Jewell, W.J., 1993. Vinyl chloride biodegradation with methanotrophic attached films. J. Environ. Eng. 119, 890-907.

Oldenhuis, R., Vink, R.L.J.M., Janssen, D.B., Witholt, B., 1989. Degradation of chlorinated aliphatic hydrocarbons by Methylosinus trichosporium OB3b expressing soluble methane monooxygenase. Appl. Environ. Microbiol. 55, 2819-2826.

Papadopoulou, A., Hedegaard, M.J., Dechesne, A., Albrechtsen, H.-J., Musovic, S., Smets, B.F., n.d. Methanotrophic contribution to phenoxy acids degradation by cultures enriched from a groundwater-fed rapid sand filter. Prep.

Phelps, T.J., Niedzielski, J.J., Schram, R.M., Herbes, S.E., White, D.C., 1990. Biodegradation of trichloroethylene in continuous-recycle expanded-bed bioreactors. Appl. Environ. Microbiol. 56, 1702-1709. 
This is a Post Print of the article: Hedegaard et al. (2018), Water Research. https://doi.org/10.1016/j.watres.2017.10.073

Prior, S.D., Dalton, H., 1985. Acetylene as a suicide substrate and active site probe for methane monooxygenase from Methylococcus capsulatus (Bath). FEMS Microbiol. Lett. 29, 105-109.

Ruiz, M.J., Redondo, M.J., Font, G., 1997. Toxicity Assessment of Pesticides Using the Microtox Test: Application to Environmental Samples. Bull. Environ. Contam. Toxicol. 59, 619-625. doi:10.1007/s001289900524

Semprini, L., McCarty, P.L., 1991. Comparison between model stimulations and field results for in-situ biorestoration of chlorinated aliphatics: Part 1. Biostimulation of methanotrophic bacteria. Groundwater 29, 365-374.

Semprini, L., Roberts, P. V., Hopkins, G.D., McCarty, P.L., 1990. A Field Evaluation of In-Situ Biodegradation of Chlorinated Ethenes: Part 2, Results of Biostimulation and Biotransformation Experiments. Groundwater. doi:10.1111/j.17456584.1990.tb01987.x

Semrau, J.D., Chistoserdov, a, Lebron, J., Costello, a, Davagnino, J., Kenna, E., Holmes, a J., Finch, R., Murrell, J.C., Lidstrom, M.E., 1995. Particulate methane monooxygenase genes in methanotrophs. These include: Particulate Methane Monooxygenase Genes in Methanotrophs 177.

Semrau, J.D., Dispirito, A.A., Yoon, S., 2010. Methanotrophs and copper. FEMS Microbiol. Rev. doi:10.1111/j.1574-6976.2010.00212.x

Semrau, J.D., Jagadevan, S., Dispirito, A.A., Khalifa, A., Scanlan, J., Bergman, B.H., Freemeier, B.C., Baral, B.S., Bandow, N.L., Vorobev, A., Haft, D.H., Vuilleumier, S., Murrell, C.J., 2013. Methanobactin and MmoD work in concert to act as the "copperswitch" in methanotrophs. Environ. Microbiol. 15, 3077-3086. doi:10.1111/14622920.12150

Sirajuddin, S., Rosenzweig, A.C., 2015. Enzymatic oxidation of methane. Biochemistry 54, 2283-2294. doi:10.1021/acs.biochem.5b00198

Smith, L.H., McCarty, P.L., 1997. Laboratory evaluation of a two-stage treatment system for TCE cometabolism by a methane-oxidizing mixed culture. Biotechnol. Bioeng. 55, 650-659. doi:10.1002/(SICI)1097-0290(19970820)55:4<650::AIDBIT7>3.0.CO;2-G

Stolyar, S., Costello, A.M., Peeples, T.L., Lidstrom, M.E., 1999. Role of multiple gene copies in particulate methane monooxygenase activity in the methane-oxidizing bacterium Methylococcus capsulatus Bath. Microbiology 145, 1235-1244. doi:10.1099/13500872-145-5-1235

Strong, P.J., Xie, S., Clarke, W.P., 2015. Methane as a resource: Can the methanotrophs add value? Environ. Sci. Technol. doi:10.1021/es504242n 
This is a Post Print of the article: Hedegaard et al. (2018), Water Research.

https://doi.org/10.1016/j.watres.2017.10.073

Sullivan, J.P., Chase, H.A., 1996. 1,2,3-Trichlorobenzene transformation by Methylosinus trichosporium OB3b expressing soluble methane monooxygenase. Appl. Microbiol. Biotechnol. 45, 427-433.

Suttinun, O., Luepromchai, E., Müller, R., 2013. Cometabolism of trichloroethylene: Concepts, limitations and available strategies for sustained biodegradation. Rev. Environ. Sci. Biotechnol. doi:10.1007/s11157-012-9291-x

Trotsenko, Y.A., Murrell, J.C., 2008. Metabolic aspects of aerobic obligate methanotrophy. Adv. Appl. Microbiol. 63, 183-229. doi:10.1016/S00652164(07)00005-6

Xu, Y., Yuan, Z., Ni, B.J., 2017. Impact of Ammonium Availability on Atenolol Biotransformation during Nitrification. ACS Sustain. Chem. Eng. 5, 7137-7144. doi:10.1021/acssuschemeng.7b01319 